\title{
Major Salivary Gland Cancer TNM Finding v8
}

National Cancer Institute

\section{Source}

National Cancer Institute. Major Salivary Gland Cancer TNM Finding v8. NCI Thesaurus. Code C132739.

A finding about one or more characteristics of major salivary gland cancer, following the rules of the TNM AJCC v8 classification system. This classification does not apply to lymphomas and minor salivary gland cancers. (from AJCC 8th Ed.) 